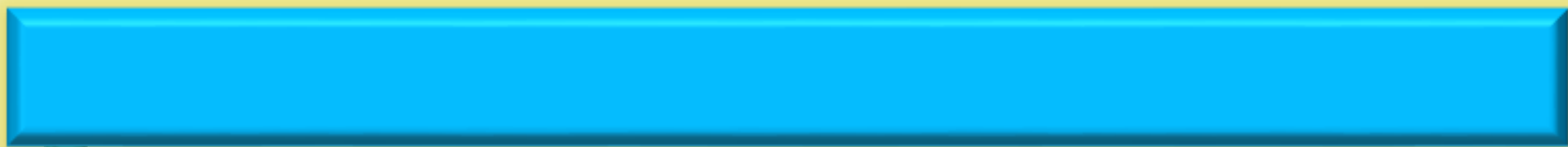

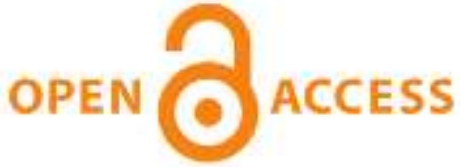

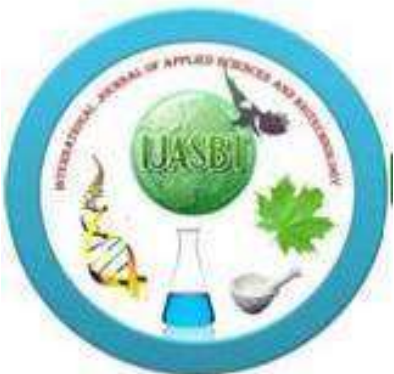 \\ International Journal of Applied Sciences and Biotechnology
}

\author{
A Rapid Publishing Journal
}

ISSN 2091-2609

\section{Indexing and Abstracting}

CrossRef, Google Scholar, Global Impact Factor, Genamics, Index Copernicus, Directory of Open Access Journals, WorldCat, Electronic Journals Library (EZB), Universitätsbibliothek Leipzig, Hamburg University, UTS (University of Technology, Sydney): Library, International Society of Universal Research in Sciences (EyeSource), Journal Seeker, WZB, Socolar, BioRes, Indian Science, Jadoun Science, JourInformatics, Journal Directory, JournalTOCs, Academic Journals Database, Journal Quality Evaluation Report, PDOAJ, Science Central, Journal Impact Factor, NewJour, Open Science Directory, Directory of Research Journals Indexing, Open Access Library, International Impact Factor Services, SciSeek, Cabell's Directories, Scientific Indexing Services, CiteFactor, UniSA Library, InfoBase Index, Infomine, Getinfo, Open Academic Journals Index, HINARI, etc.

\section{CODEN (Chemical Abstract Services, USA): IJASKD}

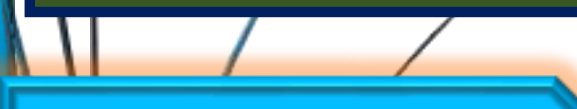

Vol-3(3) September, 2015

\section{Available online at:}

http://www.ijasbt.org

$\&$

http://www.nepjol.info/index.php/IJASBT/index

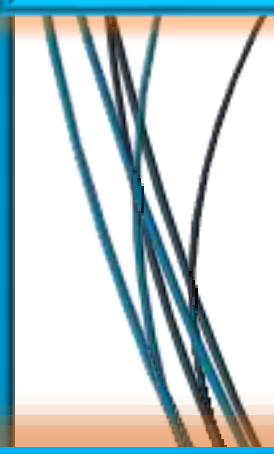

Impact factor*: $\mathbf{1 . 4 2 2}$

Scientific Journal Impact factor": 3.419

Index Copernicus Value: 6.02

SEM-Biotech

Publishing 


\title{
EXTENDED SPECTRUM BETA LACTAMASES DETECTION AND MULTIPLE ANTIBIOTIC RESISTANCE INDEXING OF ESCHERICHIA COLI FROM URINE SAMPLES OF PATIENTS FROM A REFERRAL HOSPITAL OF EASTERN NEPAL
}

\author{
A. Chakrawarti ${ }^{1 *}$, P. Dongol ${ }^{1}$, H. Khanal ${ }^{2}$, P. Subba ${ }^{2}$ and J.J. Banerjee ${ }^{3}$ \\ ${ }^{1}$ Department of Microbiology, Sunsari Technical College, Dharan, Nepal, \\ ${ }^{2}$ Department of Microbiology, Central Campus of Technology, Hattisar, Dharan, Nepal. \\ ${ }^{3}$ Department of Pharmacy, Sunsari Technical College Dharan, Nepal \\ Corresponding author's email: azureashma@gmail.com
}

\begin{abstract}
Background: Escherichia coli is the most common causative agent of urinary tract infection. Antibiotic resistance among uropathogens has become a prominent public health problem. Multidrug resistance bacteria have limited the therapeutic possibilities by producing Extended Spectrum Beta Lactamases (ESBL). Objective: Since routine monitoring of ESBL producers are not conducted in clinical laboratories their true prevalence is still unknown. So the objective of this research was to assess multiple antibiotic resistance (MAR) indices and determine ESBL production among Escherichia coli isolated from urine samples. Methods: Standard microbiological techniques and antibiotic sensitivity test were performed by Kirby Bauer disc diffusion method to identify E. coli. ESBL screening was done by using Ceftriaxone, Aztreonam, Cefotaxime, Ceftazidime and Cefpodoxime whereas confirmation by combined disc assay. SPSS 16 software was used to analyze data. Results: $86.95 \%$ E. coli isolates were MDR strains. 27 isolates had multiple antibiotic resistance (MAR) index of 0.2 and 5 isolates had MAR index of 0.7. E. coli isolates showed higher degree of resistance towards Amoxicillin (100\%) while 100\% were sensitive towards Gentamicin followed by Nitrofurantoin $(62.31 \%)$. The reliable screening agent for ESBL detection with sensitivity $100 \%$ and positive predictive value of $80 \%$ was Cefotaxime. Combined disc assay detected 12/69 (17.31\%) of E. coli isolates as confirmed ESBL producers. Conclusion: The ubiquity of ESBL-producing E. coli was observed emphasizing the necessity of regular surveillance of ESBL producing clinical isolates in clinical samples to minimize multi-drug resistance strains and avert the ineffectiveness of antimicrobial agent for good health practices.
\end{abstract}

Key words: Urine; Escherichia coli; ESBL; Multiple Antibiotic Resistance (MAR) index; MDR

\section{Introduction}

Urinary tract infection (UTI) is a common bacterial disease prevalent in community. E. coli accounts for 75.0-90.0\% of all UTIs (Dromigney et al., 2005). UTI is a common disease prevalent among Nepalese population (Kattel et al., 2008).

Antimicrobial therapy of UTI caused by E. coli has been continually weakened due to the resistance against beta lactam antibiotics. $\beta$-lactamases are the major defense of Gram negative bacteria against $\beta$-lactam antibiotics (Jacoby et al., 2005). Extended spectrum $\beta$-lactamases (ESBLs) are defined as the plasmid-mediated bacterial enzymes granting resistance to the penicillins (except temocillin), first, second and third-generation cephalosporins, and aztreonam (except cephamycins or carbapenems) but inhibited by $\beta$-lactamase inhibitors such as clavulanic acid (Paterson et al., 2005). MAR index helps to assess the spread of bacterial resistance to more than three antibiotics (Krumperman, 1983).
The emergence of MDR and ESBL E. coli pose antibiotic management problems (Lim et al., 2009). Multiple antibiotic resistances in bacteria and production of ESBL is most commonly associated with the presence of plasmids which contain one or more resistance genes, each coding a single antibiotic resistance phenotype (Paterson et al., 2005; Daini et al., 2008).

This study was designed to estimate the current prevalence and antimicrobial resistance patterns along with ESBL producing urinary isolates of $E$. coli among urinary tract infection patients visiting Bijayapur Hopsital, Dharan, Nepal.

\section{Methodology}

In a descriptive cross-sectional study conducted from March to August 2014, a total of 752 urine samples from suspected UTI patients visiting Bijayapur Hospital, Dharan were processed in the laboratory of Sunsari Technical College, Dharan for the isolation of E. coli. Informed consent was obtained for each sample used in the study from 
the patients. Each sample was mixed well and aseptically inoculated on MacConkey agar plates and incubated at $37^{\circ}$ $\mathrm{C}$ for 24 hours aerobically. Significant UTI was defined as the presence of $>10^{5}$ colony forming unit $(\mathrm{CFU}) / \mathrm{ml}$ in the culture.

Further identification of $E$. coli was done by their cultural characteristics, Gram stain and different biochemical reactions. The antimicrobial susceptibility testing (AST) of E. coli isolates was done by Kirby Bauer Disc Diffusion Method as per CLSI guideline (CLSI, 2013). E. coli ATCC 25922 was used as a reference strain.

Multiple antibiotic resistance (MAR) index was determined using the formula MAR=a/b, where "a" denotes the number of antibiotics to which test isolate showed resistance and "b" is the total number of antibiotics employed for sensitivity (Akinjogunla et al., 2010). An isolate was considered to be Multidrug Resistant (MDR) when it showed resistance to two or more drugs of different structural classes.

The test inoculum of $0.5 \mathrm{McF}$ arland was carpet cultured on Mueller-Hinton agar. The screening agents, viz. Ceftriaxone $(30 \mu \mathrm{g})$, Cefpodoxime $(10 \mu \mathrm{g})$, Ceftazidime $(30 \mu \mathrm{g})$, Aztreonam $(30 \mu \mathrm{g})$, and Cefotaxime $(30 \mu \mathrm{g})$ were placed onto the inoculated media and incubated at $37^{\circ} \mathrm{C}$ for 18-24 hours. Isolates showing Cefpodoxime $<17 \mathrm{~mm}$, Cefotaxime $<27 \mathrm{~mm}$, Ceftazidime $<22 \mathrm{~mm}$, Aztreonam $<27$ $\mathrm{mm}$, and Ceftriaxone $<25 \mathrm{~mm}$ were suspected as possible ESBL producers (CLSI, 2013).

All the processed E. coli isolates were subjected to phenotypic confirmatory test using Combined Disks Assay consisting Ceftazidime $(30 \mu \mathrm{g})$ and Ceftazidime $(30 \mu \mathrm{g})$ plus Clavulanic acid $(10 \mu \mathrm{g})$ and Cefotaxime $(30 \mu \mathrm{g})$ and Cefotaxime $(30 \mu \mathrm{g})$ plus Clavulanic acid $(10 \mu \mathrm{g})$. An increase in zone diameter of $\geq 5 \mathrm{~mm}$ in the presence of Clavulanate from either of the combination discs confirmed ESBL isolates (CLSI 2013). Data collected was analysed by using SPSS. P-value $\leq 0.05$ was considered to be statistically significant.

\section{Results}

Out of 105 positive isolates, the overall prevalence of $E$. coli was found $69.6 \%$ in total 99 Gram negative isolates. Out of 69 E. coli isolates, $60(86.95 \%)$ were multiple drug resistance and $12(17.3 \%)$ isolates were found to be ESBL producers. The isolates were highly sensitive to Gentamicin and Tobramycin (100\%) followed by Nitrofurantoin (62.31\%). All the 69 isolates of E. coli were resistance towards Amoxicillin (Table 1).

Nine multidrug resistance patterns were observed in E. coli for the seven antimicrobial agents tested. Resistance to Amx-Cz was the most frequent pattern observed in $41.7 \%$ of $E$. coli isolates, $8.3 \%$ of $E$. coli isolates showed Amx-E$\mathrm{Cz}-\mathrm{NA}-\mathrm{Nit}$ resistant pattern (Table 2). The MAR index ranges from 0.14 to 0.71 . Out of $69 \mathrm{E}$. coli isolates, only 9 showed MAR index of $0.1(<0.2) .5$ isolates showed MAR index of 0.7 i.e. these isolates were resistance to five antibiotics used in the testing (Table 3 ).

Table 1: Antibiotic susceptibility profile of E. coli

\begin{tabular}{|l|l|l|l|l|}
\hline \multirow{2}{*}{ Antibiotic used } & \multicolumn{2}{|c|}{ Sensitive } & \multicolumn{2}{c|}{ Resistant } \\
\cline { 2 - 5 } & Number & $\%$ & Number & $\%$ \\
\hline Amoxicillin & 0 & 0 & 69 & 100 \\
\hline Erythromycin & 18 & 26.08 & 25 & 36.23 \\
\hline Tobramycin & 69 & 100 & 0 & 0 \\
\hline Nitrofurantoin & 43 & 62.31 & 18 & 26.08 \\
\hline Gentamicin & 69 & 100 & 0 & 0 \\
\hline Cefazolin & 7 & 10.14 & 56 & 81.15 \\
\hline Nalidixic acid & 26 & 37.68 & 27 & 39.13 \\
\hline
\end{tabular}

Table 2: Antibiotic resistance pattern of E. coli

\begin{tabular}{|l|l|}
\hline Antibiotic resistant pattern & Number (\%) \\
\hline Amx-Cz & $25(41.7 \%)$ \\
\hline Amx-E & $1(1.6 \%)$ \\
\hline Amx-Nit & $1(1.6 \%)$ \\
\hline Amx-E-NA & $1(1.6 \%)$ \\
\hline Amx-E-Cz & $3(5 \%)$ \\
\hline Amx-Cz-NA & $3(5 \%)$ \\
\hline Amx-Cz-Nit & $6(10 \%)$ \\
\hline Amx-E-Cz-NA & $9(15 \%)$ \\
\hline Amx-E-Cz-Nit & $6(10 \%)$ \\
\hline Amx-E-Cz-NA-Nit & $5(8.3 \%)$ \\
\hline Total & $60(100 \%)$ \\
\hline
\end{tabular}

Table 3: Multiple antibiotic resistance index of E. coli

\begin{tabular}{|l|l|}
\hline MAR Index & $\begin{array}{l}\text { Frequency of MAR index } \\
\boldsymbol{E} \text {. coli }(\mathbf{n = 6 9 )}\end{array}$ \\
\hline 0 & $0(0.0 \%)$ \\
\hline 0.1 & $9(13.04 \%)$ \\
\hline 0.2 & $27(39.13 \%)$ \\
\hline 0.3 & $0(0.0 \%)$ \\
\hline 0.4 & $13(18.84 \%)$ \\
\hline 0.5 & $15(21.73 \%)$ \\
\hline 0.6 & $0(0.0 \%)$ \\
\hline 0.7 & $5(7.24 \%)$ \\
\hline 0.8 & $0(0.0 \%)$ \\
\hline 0.9 & $0(0.0 \%)$ \\
\hline 1.0 & $0(0.0 \%)$ \\
\hline
\end{tabular}

Among the ESBL screening drug, Cefotaxime displayed sensitivity and positive predictive value (PPV) of $100 \%$ and $80 \%$ respectively. Ceftazidime displayed the lowest sensitivity of $83.3 \%$ and a PPV of $62.5 \%$. Despite of having 91.6\% sensitivity, both Ceftriaxone and Cefpodoxime had lower PPV of $73.3 \%$ (Table 4). The Cefotaximeclavulanate and Ceftazidime-clavulanate combined disk detected 12 E. coli to be ESBL confirmed isolates. 
Table 4: Screening of $E$. coli isolates for ESBL production

\begin{tabular}{|c|c|c|c|c|c|}
\hline Screening Agents & \multicolumn{2}{|c|}{ ESBL Screening } & $\begin{array}{l}\text { No. of confirmed } \\
\text { ESBL producers }\end{array}$ & Sensitivity (\%) & $\begin{array}{l}\text { Positive predictive } \\
\text { value (PPV) }\end{array}$ \\
\hline \multirow{2}{*}{ Ceftriaxone $(30 \mu \mathrm{g})$} & Screen positives & 15 & 11 & \multirow{2}{*}{91.6} & \multirow{2}{*}{73.3} \\
\hline & Screen negatives & 54 & 1 & & \\
\hline \multirow{2}{*}{$\begin{array}{l}\text { Cefpodoxime } \\
(10 \mu g)\end{array}$} & Screen positives & 15 & 11 & \multirow{2}{*}{91.6} & \multirow{2}{*}{73.3} \\
\hline & Screen negatives & 54 & 1 & & \\
\hline \multirow{2}{*}{ Ceftazidime $(30 \mu \mathrm{g})$} & Screen positives & 16 & 10 & \multirow{2}{*}{83.3} & \multirow{2}{*}{62.5} \\
\hline & Screen negatives & 53 & 2 & & \\
\hline \multirow{2}{*}{ Cefotaxime $(30 \mu \mathrm{g})$} & Screen positives & 15 & 12 & \multirow{2}{*}{100} & \multirow{2}{*}{80} \\
\hline & Screen negatives & 54 & 0 & & \\
\hline \multirow{2}{*}{ Aztreonam $(30 \mu \mathrm{g})$} & Screen positives & 18 & 10 & \multirow{2}{*}{83.3} & \multirow{2}{*}{55.5} \\
\hline & Screen negatives & 51 & 2 & & \\
\hline
\end{tabular}

\section{Discussion}

In this study, the overall prevalence of E. coli was found to be $69(65.7 \%)$ in total 105 isolates. Similar result was reported by Sharma et al.(2011) who found $67.5 \%$ E. coli. Most of the $E$. coli isolates showed the multidrug resistant $(86.95 \%)$ in agreement with other studies (Bashar et al., 2009; Moyo et al., 2010; Hassan et al., 2011; Sharma et al., 2013). This study demonstrated $100 \%$ resistant of $E$. coli isolates to Amoxicillin which was similar to previously reported finding (Khadgi et al., 2013). Resistance to penicillins may be determined by the organisms due to the production of penicillin destroying enzymes such as betalactamase (Forbes et al., 2007).

With the highest sensitivity and PPV cefotaxime was found the most reliable agent for ESBL screening test. This result matches with other findings (Ho et al., 2000; Poudyal et al., 2011). TEM-1, TEM-2, and SHV-1 $\beta$-lactamases are the primary causes for resistance towards $\beta$-lactam antimicrobial agents among gram negative rods (Livermore, 1995). Two isolates screened as ESBL screen negatives by Ceftazidime, however, were found ESBL producers on confirmatory test. This suggests the possible production of CTX-M type ESBL by these isolates (Bush, 2008). CTX-M ESBLs differ from TEM and SHV types as they hydrolyse Cefotaxime and Ceftriaxone better compared to Ceftazidime (Lewis et al., 2007). Out of 69 E. coli isolates, 12 (17.39\%) confirmed to be ESBL positive. This result is in harmony with previous study (Chander et al., 2013).

\section{Conclusion}

This study reveals that E. coli is the most predominant pathogen in urinary tract infection accounting for $65.7 \%$ in total positive isolates. ESBL producers were found higher in females $11(91.6 \%)$ than males 1 (8.3\%). The prevalence of MDR E. coli isolates was high i.e. $86.95 \%$. Likewise, MAR index data revealed that isolates with lowest and highest MAR index are present in our surrounding that can pose health hazards.

The prevalence of ESBL producers was 17.39\% among total E. coli. Ceftazidime had the lowest sensitivity detecting ESBL producers and can miss CTX-M producing bacteria thus signifying use of more than one screening agents and combination disk assay for more reliable detection of ESBL. Hence this kind of study aids in evaluating the exact cause and mechanism of rapid development of antibiotic resistance by bacteria.

\section{Acknowledgement}

We would like to thanks all the faculty members of department of microbiology, pharmacy, pathology and management committee of Sunsari Technical College and Bijayapur Hospital of Dharan, Nepal, for their kind support to this research.

\section{References}

Akinjogunla OJ and Enabulele IO (2010) Virulence factors, plasmid profiling and curing analysis of multidrug resistant Staphylcococus aureus and coagulase negative Staphylococcus spp. isolated from patients with acute otitis media. Journal of American Science 6(11): 10221033.

Bashar MA, Ahmed MF, Rahman SR and Gomes DJ (2009) Distribution and resistance trends of Escherichia coli from urinary tract infection isolated in Dhaka city. Bangladesh J Med Sci 15(2): 93-98. 
Bush K (2008) Extended-spectrum $\beta$-lactamases in North America, 1987-2006. Clin Microbiol Infect 14 (Suppl 1): 134-143. DOI: 10.1111/j.1469-0691.2007.01848.x

Chander A and Shrestha CD (2013) Prevalence of extended spectrum beta lactamase producing Escherichia coli and Klebsiella pneumoniae urinary isolates in a tertiary care hospital in Kathmandu, Nepal. BMC Res Notes 6:487. DOI: $10.1186 / 1756-0500-6-487$

CLSI (2013) Performance standards for antimicrobial susceptibility testing; $23^{\text {rd }}$ informational supplement (M100-S23). Clinical and Laboratory Standard Institute, Wayne, PA.

Daini OA, Effiong MJ and Ogbolu OD (2008) Quinolones Resistance and R-Plasmids of Clinical Isolates of Pseudomonas species. Sudan J M Sci. 3: 139-146. DOI: 10.4314/sjms.v3i2.38528

Dromigny JA, Nabeth P, Juergens, Behr A and et al. (2005) Risk factors for antibiotic resistant Escherichia coli isolated from community acquired urinary tract infections in Dakar, Senegal. J Antimicrob Chemother. 56: 236-239. DOI: $10.1093 /$ jac/dki158

Forbes BA, Sahm DF and Weissfeld AS (2007) Bailey and Scott's Diagnostic Microbiology $12^{\text {th }}$ edition. Mosby Elsevier Publication, USA pp 842-846.

Hassan SA, Jamal SA and Kamal M (2011) Occurrence of multidrug resistant and ESBL producing $E$. coli causing urinary tract infections. J Basic Appl Sci. 7(1): 39-43.

Ho PL, Tsang DNC, Que TL, Ho M and Yuen KY (2000) Comparison of screening methods for detection of extended-spectrum $\beta$-lactamases and their prevalence among Escherichia coli and Klebsiella species in Hong Kong. APMIS 108: 237-240. DOI: 10.1034/j.16000463.2000.d01-50.x

Jacoby GA and Munoz-Price LS (2005) The New $\beta$-Lactamases. N Engl J Med. 352(4): 380-391. DOI: 10.1056/NEJMra041359

Kattel HP, Acharya J, Mishra SK, Rijal BP and Pokhrel BM (2008) Bacteriology of urinary tract infection among patients attending Tribhuvan University Teaching Hospital, Kathmandu, Nepal. JNAMLS. 9(1): 25-29.

Khadgi S, Timilsina U and Shrestha B (2013) Plasmid profiling of multidrug resistant Escherichia coli strains isolated from urinary tract infection patients Int J Appl Sci Biotechnol. 1(1): 1-4.

Krumperman PH (1983) Multiple antibiotics resistance indexing of $E$. coli to identify high risks sources of faecal contamination of foods. App Environ Microbiol. 46: 165170.

Lewis JS, Herrera M, Wickes B, Patterson JE and Jorgensen JH (2007) First Report of the Emergence of CTX-M-Type Extended-Spectrum-Lactamases (ESBLs) as the Predominant ESBL Isolated in a U.S. Health Care System. Antimicrob Agents Chemother. 51(11): 4015-4021. DOI: 10.1128/AAC.00576-07

Lim KT, Yasin RM, Yeo CC, Puthucheary SD, Balan G, Maning N, Wahab ZA, Ismail N, Tan EA, Mustaffa A, Thong KL (2009) Genetic fingerprinting and antimicrobial susceptibility profiles of Pseudomonas aeroginosa hospital isolates in Malaysia. J Microbiol Immunol Infect. 42: 197-209.

Livermore DM (1995) $\beta$-Lactamases in laboratory and clinical resistance. Clin Microbiol Rev. 8: 557-584.

Moyo SJ, Aboud S, Kasubi M, Lyamuya EF and Maselle SY (2010) Antimicrobial resistance among procedures and non-producers of extended spectrum beta-lactamase in urinary isolates at a tertiary hospital in Tanzania. BMC Res Notes. 3: 348. DOI: 10.1186/1756-0500-3-348

Paterson DL and Bonomo RA (2005) Extended-Spectrum $\beta$ lactamase: a Clinical Update. Clin Microbiol Rev. 18 (4): 657-686. DOI: 10.1128/CMR.18.4.657-686.2005

Poudyal S, Bhatta DR, Shakya G, Upadhyaya B, Dumre SP, Buda G (2011) Extended spectrum $\beta$-lactamase producing multidrug resistant clinical bacterial isolates at National Public Health Laboratory, Nepal. Nepal Med Coll J. 13(1):34-38.

Sharma A, Shrestha S, Upadhyay S and Rijal P (2011) Clinical and bacteriological profile of urinary tract infection in children at Nepal Medical College Teaching Hospital. Nepal Med Coll J. 13(1): 24-26.

Sharma AR, Bhatta DR, Shrestha J and Banjara MR (2013) Antimicrobial Susceptibility Pattern of Escherichia coli Isolated from Urinary Tract Infected Patients Attending Bir Hospital. Nepal Journal of Science and Technology 14(1): 177-184. DOI: $10.3126 / n j s t . v 14 i 1.893$ 